\title{
Coastal Inundation Adaptive Strategy in Semarang Coastal Area
}

\author{
Ifan R Suhelmi ${ }^{*}$, Hariyanto Triwibowo \\ Badan Riset dan Sumber Daya Manusia Kelautan dan Perikanan, J1 Pasir Putih 1 Ancol Timur \\ Jakarta Telp : (021) 64711583, Fax : (021) 64711654 \\ *) Corresponding author (e-mail: ifan_ridlo@yahoo.com)
}

\begin{abstract}
Semarang Coastal has a high level of vulnerability to inundation, river flooding and tidal flooding. To solve the problems, a region has an adaptive capacity to the phenomena encountered. The aims of study to map the level of vulnerability and adaptive capacity of the region in facing the phenomenon and provide an alternative strategy in facing the impact of inundation in coastal areas. Based on capacity index and vulnerability index in 2015, most urban villages are located in quadrant 3 (58 villages), in quadrant 1 (36 villages) and quadrant 4 (5 villages). the results showed that most of villages located at coastal areas had a high vulnerability with low adaptive capacity. Considering spatial planning (RTRW) for 2030, population density changes, Semarang City Facility health facilities Plan in 2030, and the open areas as defined in the Semarang 2011-2030 spatial plan (RTRW) a major shift towards the quadrant 2 was observed, suggesting an increased capacity to encountered inundation susceptibility.
\end{abstract}

Keywords: adaptation strategy, adaptive capacity, coastal vulnerability.

\begin{abstract}
Abstrak. Pesisir Kota Semarang dapat dikategorikan sebagai wilayah dengan tingkat kerentanan yang tinggi terhadap genangan, baik genangan akibat banjir dari darat maupun genangan akibat rob air laut. Dalam menghadapi permasalahan tersebut, suatu wilayah mempunyai kapasitas adaptif terhadap fenomena yang dihadapi. Penelitian ini bertujuan untuk memetakan tingkat kerentanan (Vulnerability) dan kapasitas adaptif wilayah (Capability) dalam menghadapi fenomena dan memberikan gambaran strategi alternatif dalam menghadapi dampak genangan di wilayah pesisir. Berdasarkan hasil kajian indek kapasitas dan indek kerentanan untuk tahun 2016 menunjukkan bahwa sebagian besar kelurahan berada pada kuadran 3 (58 kelurahan), pada kuadran 1 (36 kelurahan) dan pada kuadran 4 (5 kelurahan). Hal ini menunjukkan sebagian besar wilayah pesisir Kota Semarang memiliki kerentanan yang cukup tinggi dengan kapasitas adaptif yang rendah. Setelah melihat upaya dan rencana penyusunan tata ruang untuk tahun 2030, perubahan kepadatan penduduk, sarana kesehatan berdasarkan Rencana Fasilitas Kota Semarang pada tahun 2030, dan area terbuka non-hijau sebagaimana didefinisikan dalam rencana tata ruang revisi Semarang 2011-2030 menunjukkan pergeseran sebagian besar menuju kuadran 2 yang berarti kapasitass meningkat dalam menghadapi kerentanan genangan.
\end{abstract}

Kata kunci: strategi adpatasi, kapasitas adaptif, kerentanan pesisir.

\section{Introduction}

Semarang Coastal Areas can be categorized as areas which are highly vulnerable to inundation, either inundation from river flood or tidal flood. To overcome such problems, an area has an adaptive capacity to the phenomena encountered. Tidal flood is defined as the flood occurring to low-elevation areas in coastal areas, including estuaries and deltas, which are inundated by brackish water or seawater (Marfai, 2004). The river flood is caused by river stream overflowing. It is overflowing from either side of the rivers that further empties into the sea or in the proximity to the coastal areas and is often inundated during 
the rising tide. Floods cause inundation, which can be defined as low elevation where water cannot flow to another place (Gerald, 1992 in Wibowo, 2006). Inundation is not only caused by slow-onset phenomena, such as sea level rise (Huang et al. 2004 and Denirkesen et al. 2008), but also by sudden natural phenomena, like tsunami (Kumar et al. 2008).

River and tidal floods are one of the problems that have to be encountered by people in Semarang coastal areas. These phenomena can be influenced by various modifications of the landforms by human activities. Modifications to coastal landforms, for instance reclamation have a major impact on coastal disasters (Petrucci and Polemio, 2007). Tidal flood is a natural phenomenon that usually happens at the full moon. During this time, the moon's gravitational force against the earth is so powerful that the seawater movement towards the coast is stronger, prompting the seawater to rise on the land with a lower elevation than the highest tide. Besides full moon phenomena, sea level rise could also be the cause of the inundation (Titus et al, 1991). Tidal flood is commonly occurred in alluvial coastal plains located at low land areas, or in the form of basins with many rivers.

To minimize the impact of disaster caused by climate change phenomenon, various adaptations to existing threats have been done. Various adaptations have long been formulated in the face of climate change as formulated by the IPCC (Adger et. al. 2003). To encounter of sea level rise caused by climate change, there are 3 (three) adaptations, i.e. protection, accommodation, and retreat. Disaster adaptation capacity should be increased institutionally, socially and implemented by the government (Pelling et. al. 2008).

Semarang City Government has made various efforts to minimize the impacts of the floods. It is an effort to increase the capacity of a region in the encounter of disasters. The objective of the present study is to map the vulnerability level and adaptive capability of the region to encounter the the phenomenon and providing an alternative strategy to solve the inundation impacts in coastal areas.

\section{Methods}

The study was conducted in Semarang City, Central Java Province as shown in Figure 1. This research is an advanced study of vulnerability mapping and adaptive capacity of Semarang City (Suhelmi and Prihatno, 2014). Semarang city as capital city of Central Java Provinces is located at $110^{\circ} 21^{\prime}$ to $110^{\circ} 50^{\prime}$ east longitude and $6^{\circ} 50^{\prime}$ to $7^{\circ} 10^{\prime}$ south latitude. It has an area of $373,70 \mathrm{~km}^{2}$ with administrative boundaries: the Java Sea at the north, Semarang Regency at south, Kendal Regency at west, and Demak and Grobogan Regencies at east. Administratively, Semarang City is classified into 16 sub-districts and 177 sub-districts.

Flood and inundation of coastal area in the Semarang City can be classified as flooding from hinterland, local flood and tidal flood. The handling of flood from hinterland was strongly influenced by poor management of drainage, the pattern of arrangement and management of the area of the river in the upstream area in the scope of cross-regions. Local flood management was more influenced by the arrangement and management pattern of the area within the scope of the Semarang City Region. While tidal floods was more due to the need of handling coastal areas.

There were several tools to determine the vulnerability of a region. To determine the vulnerability level of the area against the inundation used eight parameters based on ACCCRN (2010) and Miladan (2009) as presented in Table 1, namely road network, percentage of constructed land, drinking water source, population density, poverty, coastal border area, river border area, percentage of mangrove cover/water catchment area. Susceptibility index was determined using Equation 1 . Where $V I$ is the total susceptibility index of a village, $w_{i j}$ is the weight of a vulnerability indicator of $\mathrm{i}$ in village $\mathrm{j}$, and $V_{i j}$ is the value of a indicator of $i$ in village $j$. 




Figure 1. Research Site

Table 1. Indicators used to define the vulnerability and capacity and weight.

\begin{tabular}{|c|c|c|c|c|c|}
\hline $\mathrm{V}$ & Vulnerability & Weight & $\mathrm{C}$ & Capacity & Weight \\
\hline $\mathrm{B} 1$ & Road network & 0.40 & A1 & Phone network & 0.20 \\
\hline B2 & $\begin{array}{l}\text { Percentage of } \\
\text { Underdeveloped land }\end{array}$ & 0.40 & $\mathrm{~A} 2$ & $\begin{array}{l}\text { Workers based on } \\
\text { education background }\end{array}$ & 0.30 \\
\hline B3 & Drinking water source & 0.20 & A21 & $\begin{array}{l}\text { Kindergarten - } \\
\text { Secondary School }\end{array}$ & 0.30 \\
\hline B31 & Good & 0.10 & A24 & High School/University & 0.70 \\
\hline B32 & Moderate & 0.20 & A3 & Main Subsistence & 0.30 \\
\hline B33 & Poor & 0.30 & A4 & Health Facilities ${ }^{\star}$ & 0.20 \\
\hline B34 & No service & 0.40 & $\mathrm{~A} 41$ & Public Health Centre & 0.20 \\
\hline B4 & Population density & 0.10 & $\mathrm{~A} 42$ & Polyclinic & 0.30 \\
\hline B5 & Poverty & 0.20 & A 43 & Integrated Health Centre & 0.20 \\
\hline B6 & Coastal border region & 0.10 & A 44 & Midwife Practice Sites & 0.10 \\
\hline B7 & River border region & 0.10 & A 45 & Physician Practice Sites & 0.20 \\
\hline B8 & $\begin{array}{l}\text { Percentage of mangrove } \\
\text { cover/ water catchment } \\
\text { areas }\end{array}$ & 0.20 & A5 & Road Infrastructure & 0.20 \\
\hline
\end{tabular}

Source: ACCRN, 2010, Miladan, 2009, with modification

$$
V I=\sum_{j=1}^{8} w_{i j} x V_{i j}
$$

To count the regional capacity index due to inundation, ACCCRN (2010) and Miladan (2009) methods were used. There are 5 (five) parameters: Telephone Network, Workers based on Educational Background, Main Source of Subsistence, Health Facilities, and Road Infrastructure. Indicators of health facilities were divided into 5 sub-indicators: the number of Polyclinic (Poliklinik, Pl), Integrated Health Service (Posyandu, Ps), Public Health Care (Puskesmas, Pk), Midwife Clinic (Klinik Bidan, B) and Physician Clinic (Klinik Dokter, D). All sub-indicator values are normalized with the total population of the villages in question. The scores in each IA4 Villages were calculated using the formula by ACCCRN (2010) given in equation 2 . While the total capacity index was calculated using Equation 3, which is the sum of 
multiplication between capacity determinants and the weight of each indicator (ACCCRN, 2010). Where $C I$ is the total capacity index of a village, $w_{i j}$ is the weight of a capacity indicator of $i$ in village $j$, and $C_{i j}$ is the value of a indicator of $i$ capacity in village $j$.

IA $4 \mathrm{i}=1 / \mathrm{Pi}{ }^{*}\left(0.3^{*} \mathrm{Pli}+0.2^{*} \mathrm{Psi}+0.2^{*} \mathrm{Pki}+0.1^{*} \mathrm{Bi}+\right.$ $0.2 * \mathrm{D}$

$$
C I=\sum_{i=1}^{5} w_{i j} x C_{i j}
$$

Village were grouped based on vulnerability and capacity; all values of VI and CI of all villages were subtracted by 0.5 . Initially, the VI and $\mathrm{CI}$ values ranged from 0 to 1 . After subtraction, the values of VI and CI would range from -0.5 to 0.5 . The relative positions of sub-villages were determined based on their CI and VI values and classified into five Quadrants as shown in Figure 2. The villages located in Quadrant 5 will have low $\mathrm{CI}$ and high VI, while those located in quadrant 1 will have low VI and high CI. Based on this classification system, if the village located in Quadrant 5 were affected by a particular disaster, the impact would be worse than that in Quadrant 1.

To assess changes in vulnerability and adaptive capacity in the future, several indicators were considered, among others for flood-vulnerable areas due to sea level rise, changes in population density (based on government projections), health facilities (based on Semarang Facilities Plan in 2031), and open areas as defined in the Semarang 2011-2031 spatial plan (Regional Revenue Management Agency, 2011).

\section{Result and Discussion}

An adaptation is a physical or behavioural characteristic that is developed to allow an organism to better survive in its environment. It is a key component of endurance; the more adaptive a person or society is, then the more likely they will be able to survive with the changes that may occur. In the present study, adaptations that have been developed by the community and individuals were discussed, and new strategies for adaptations in the future were proposed (Miladan, 2009).

Various analyses related to adaptation and the action to encounter of varying inundation scenarios occurring as a result of sea level rise were conducted. The Vulnerability index was mapped to every sub-district to show the possibility being inundated due to rising sea levels and flooding. Vulnerability analysis was carried out for each sub-district, each village has a certain vulnerability value. The indicators used to determine the vulnerability of an urban village were the percentage of road network that was inundated by rob, the percentage of built-up area inundated due to rob, the source of clean water used by residents, the number and density of population, poverty level, local protection area in the form of coastal borders and river borders, and a broad percentage of green open space. While the capacity index was conducted to analyze the area capacity in dealing with disasters. There are 5 (five) indicators were used to describe the capacity of the region to face of disasters, i.e. the installed telephone network per sub-district, workers based on education, main livelihood sources, existing health facilities in the sub-district and the length of road classes owned by a subdistrict. This capacity value will have a range between 0 to 1 which means low capacity so that high capacity in dealing with disasters. Each indicator has a certain weight according to the size and contribution in determining the capacity index. The analysis results are presented in a quadrant as shown in Figure 3.

In Semarang city, River flood and tidal flood incidents have been going on for a long time with widespread impacts, which are considered major disasters. To overcome the problems caused by these phenomena, supports from various parties, including the government, provincial government, international cooperation agencies and donor agencies are highly needed. The institutions that focused in handling of river and tidal flood are Directorate General of Water Resources (SDA) and Directorate General of Human Settlements at the Ministry of Public Works. The Directorate General of Water Resources via 
its vertical institution, namely River Institute of Pemali, Juwana (Balai Besar Sungai Pemali Juwana) shows an interest in the handling of flooding alongside the basin of Banjir Kanal Barat River, where there are 6 rivers emptying directly towards the sea along the north coast of Semarang. Meanwhile, Directorate General of Human Settlements puts an interest in the settlement, drainage and sanitation arrangement in areas commonly affected by flood and seawater flood (ACCCRN, 2010).

ACCCRN (2010) argued that to solve flood problem, international cooperation agencies and governments of other countries also played many roles, especially in helping to conduct studies and preparation of Semarang flood master plan. The government of Japan through JICA, greatly helped in the construction of flood management system megaproject which was worth IDR 1.7 trillion in Goa Kreo. The megaproject completed in 2013 was expected to overcome river and tidal flood in seven districts located in Semarang. Meanwhile, the Dutch government helped through Hoogheemraadschap van Sceieland en de Krimpenerwaard (HHSK), and Semarang City government build Banger Pilot Polder Project. Central Java province government as a direct vertical agency has also shown a role to solve the floods that is by coordinating and facilitating regional cooperation and providing technical facilitation and coordination assistance through provincial budgets.

Semarang City Government, as a major stakeholder in the solving problem of river and tidal flood, certainly has a major role and duty in handling flood and seawater problems. Many agencies and institutions have been involved directly and indirectly in handling the flood in Semarang, including Office of Public Works, Department of Fire and Disaster Mitigation, as well as Regional Disaster Management Agency of Semarang. Non-government institutions have equally important roles, both private and non-governmental organizations, and other community organizations in handling river and tidal floods, and the impacts.
Environmental-oriented development policies provide space for developing the capabilities and application of early detection systems, dissemination of information, and early dissemination of threats to the vulnerability of natural disasters to the communities. The identification and mapping of disaster-vulnerable areas are therefore necessary to make early anticipation prior to disaster occurrence. It can provide great benefits to the community and protection to people and their property, by means of making area planning to those related/ sensitive to natural disasters.

From Capacity Index and Vulnerability Index in 2015, it is observed that most villages are located in quadrant 3 (58 urban villages), in quadrant 1 (36 villages), and in quadrant 4 (5 villages). The existing condition is a baseline condition that will be used to take a projection at the condition in 2030. Most villages have large adaptive capacity for inundation. Based on field observations, it was observed that people living in vulnerable locations could survive on inundated and subsidence area. It was indicated by the continuous physical development by government. One of government's efforts in tackling tidal flood was road elevation. However, this elevation gave impact to the houses surrounding the road. The houses around the road must adapt to the height of the road because their location was lower than the road. The community had to compete with the height of the road when building their houses as the road elevation program could be performed every 5-10 years. Based on the vulnerability index by 2015, most villages are below the $x$ axis meaning that they are in medium to low vulnerability; only 10 (ten) districts have positive vulnerability values. Of the 10 villages, only 5 (five) villages are in quadrant 4. As mentioned previously, quadrant 4 means a classification with higher vulnerability and requires high priority. So, villages belonging into quadrant 4 have higher vulnerability and need priority in the handling. 




Figure 3. Capacity Index and Village Vulnerability Index in 2010

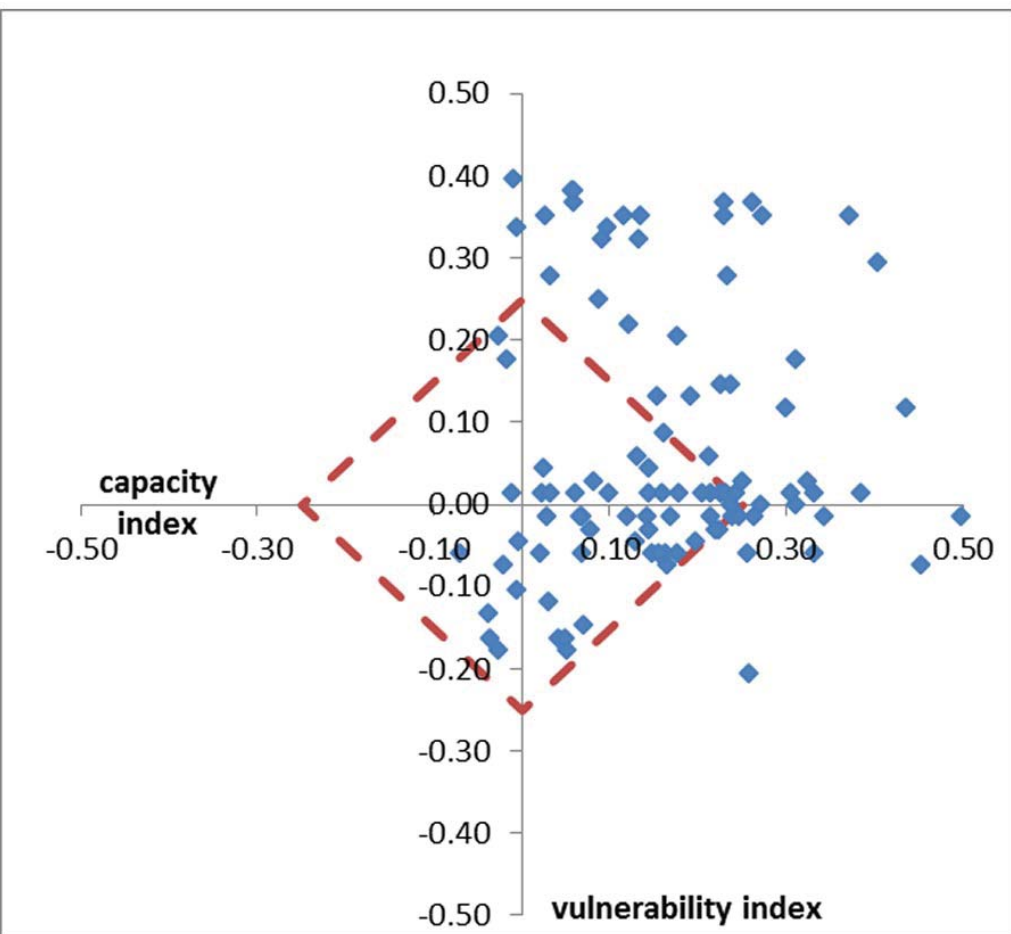

Figure 4. Capacity Index and Village Vulnerability Index by 2030

Assessment of future vulnerability index and adaptive capacity index were done by considering population density, health facilities (based on Semarang Facility Plan in 2031), and open areas as defined in 2011-2031 Semarang
Regional Plan (Bappeda, 2011). Inundation susceptibility to roads and constructed areas was based on predicted flooding by 2030 (Suhelmi, 2013). 


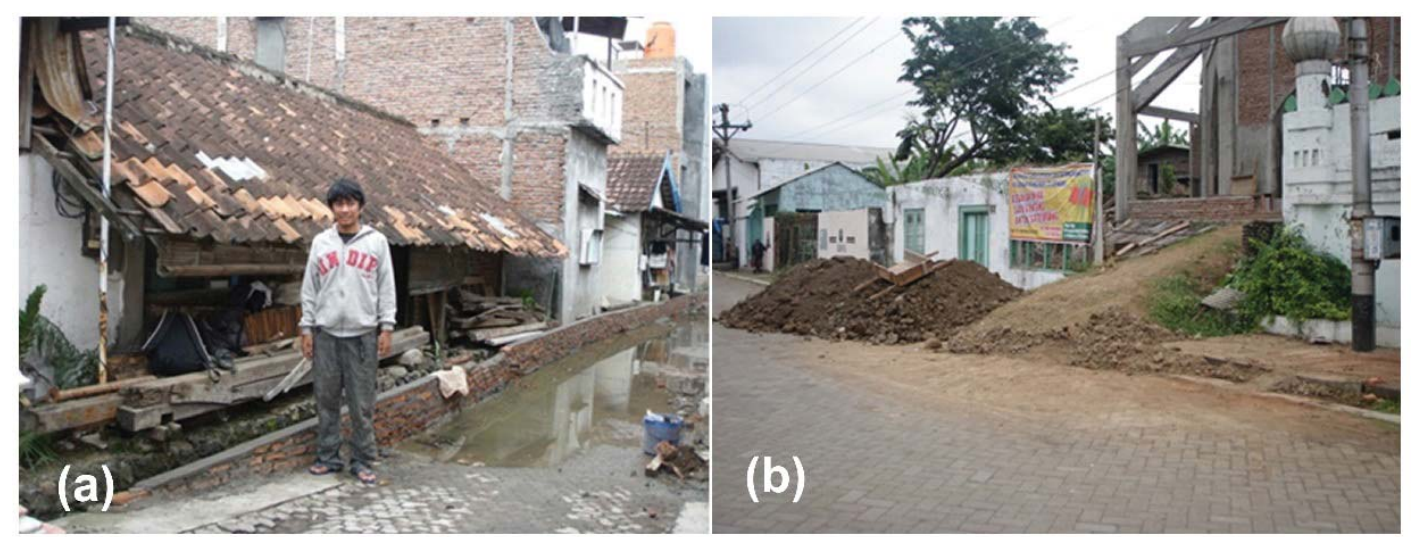

Figure 5. Adaptation efforts by elevating the road and building embankments around the house (a), elevating the house by landfill material (b).

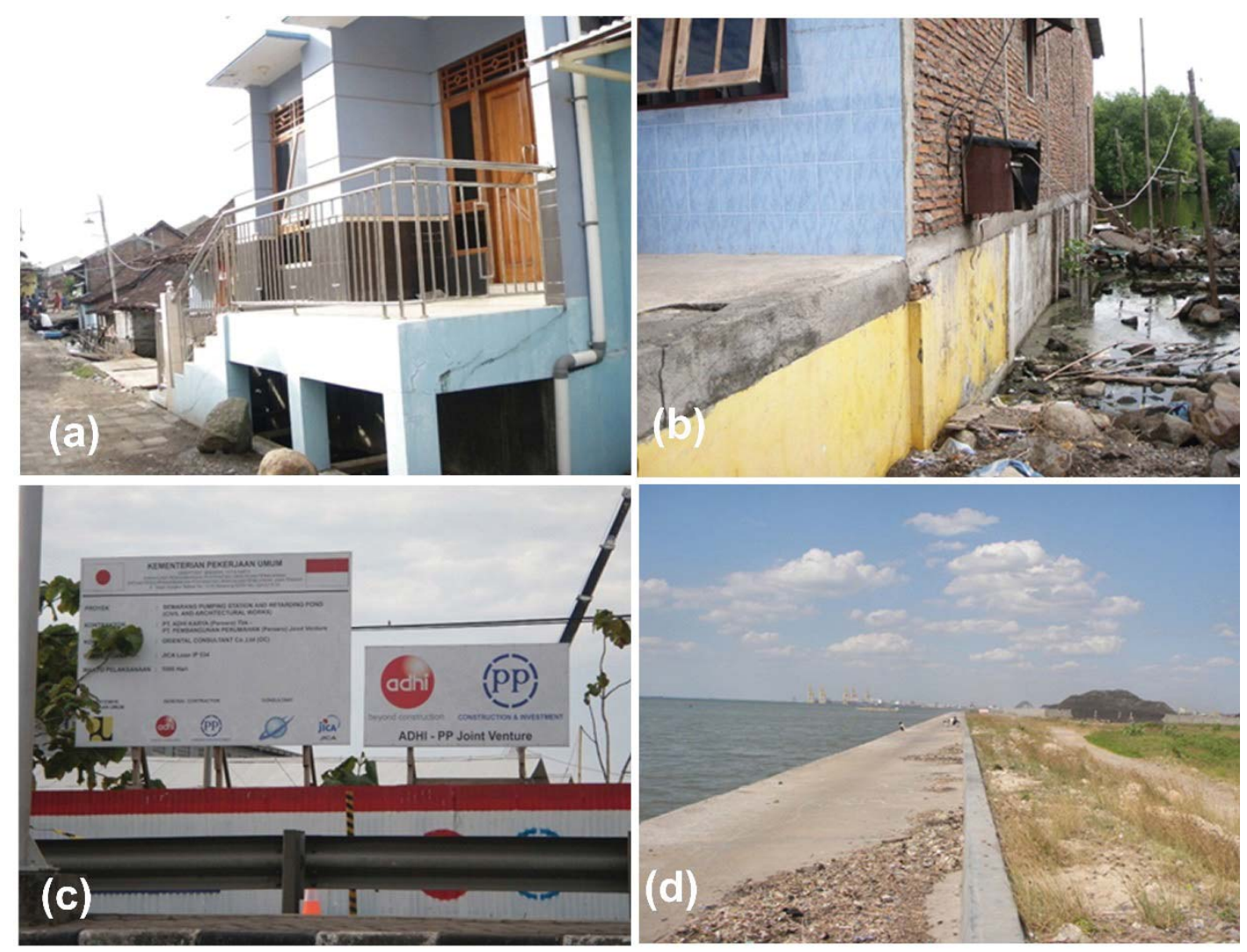

Figure 6. Varying strategies for handling seawater flood, for instance building house on stilts (a), elevating the house (b), building a polder banger (c) and building reclamation (d).

The analysis result showed that there was a susceptibility shift that caused a shift in the quadrant occupied by the villages. The prediction results of the capacity index and susceptibility index indicated that most villages have increased susceptibility class, thus villages spread is increased in quadrant 4 . It means the villages have a high capacity, but with high vulnerability to tidal flood.
In accordance with the adaptive concept proposed by Nichols et al. (2008) and Diposaptono (2009), to encounter of sea level rise, there were 3 (three) adaptations that can be done, i.e. protection, accommodation and retreat. According to the increasing number in facilities provided in Regional Spatial Plans (RTRW) by 2030, the city took both protection and accommodation to face the 
coastal inundation. The protection strategy could use both hard structures (e.g. solid breakwaters) and soft structures (e.g. the use of vegetation for coastal protection). The accommodation strategy that can be done was building buildings that are adapted to natural conditions, for instance stilts or floating houses. On the other hand, the retreat strategy is a strategy by avoiding locations that have high vulnerability.

Presidential Regulation No. 64/2010 on Coastal Disaster Mitigation mentioned several efforts to address the sea level rise: (1) Construction of coastal protection structure, (2) Provision of water pumps for handling tidal flood and mitigation, (3) Use of construction materials to adapt to sea level rise, (4) Coastal vegetation, and (5) Management of coastal ecosystem.

To handle of tidal flood disasters occurred in Semarang, which was dominated by land subsidence, Suryanti and Marfai (2008) suggested a number of adaptations that could be done by coastal communities to prepare for tidal flood disasters. They were (1) Creating small embankments inside the house, (2) Elevating the road up to 1-1.5 $\mathrm{m}$ to maintain accessibility, (3) Building permanent and nonpermanent dikes and roofs at shore, (4) Building house on stilts and (5) Building artesian wells for clean water.

Based on the vulnerability aspect, the vulnerability value is predicted to increase into vulnerable class and moderate class. Several adaptation efforts should be made, not only using one strategy, but also with various combinations. It could be seen that the Semarang City has made various efforts to deal with inundation threats. The strategy was taken in the form of a combination of protection and accommodation. Both methods were taken because this region was a densely populated city. Semarang City Government has made several projects that can be categorized as a protective strategy to encounter river and tidal flood. Several development projects that would affect coastal vulnerability were (1) Banger Polder Project Construction, as a part of cooperation with the Netherlands and funding from JBIC (Japan Bank for International Cooperation). The polder construction was expected to reduce flood in the northern and eastern regions of Semarang, (2) Jatibarang Reservoir Construction, as a part of cooperation with JBIC (Japan Bank for Infrastructure Cooperation). The construction of the reservoir was expected to boost the raw water supply for Tap Water Company, and reduce the pressure on clean water needs especially in the dry season, and (3) Seawall Development. The seawall would stretch across the northern part of the city. The construction of seawall became an issue ignited by Semarang City Government to encounter river and tidal flood.

These three projects were arguably regarded as megaprojects in Semarang, where their existence in the scenario development analysis should be noted. The completed project was the construction of Polder Banger which was completed in 2013. The combination of protective strategy and an accommodative strategy was aimed at tidal flood-affected locations. For the protective effort can be seen at the location affected by the soil subsidence. The landfill was independently conducted by the community. The landfill was done in several stages at a certain time interval, adapted to the financial condition. Thereby arising a proverb said that owning the land there feels like renting, because within 5-10 years, the floor needed to be elevated, further requiring to change the ceiling and elevate the house. Thus, in certain interval, there were many floors shown at the present time that were actually the product of roof backfill from 10-20 years ago.

\section{Conclusion}

Semarang Coastal Area has a high level of vulnerability to coastal inundation, nevertheless it shows a good adaptive capacity because it was supported by good facilities. Increasing facility provided on Regional Spatial Plans (RTRW) by 2030, Semarang would have owned better capacity, which means the ability to encounter inundation. It was also observed that most village areas in Semarang were in Quadrant 2. Semarang city government and the community were highly active in encountering 
the potential inundation with various strategies (e.g. building the infrastructure); the community is actively adapting to the existing inundation. This study illustrates that adaptive capacity and vulnerability capacity could be used as a basis for future decisions making. Both protective and accommodative strategies taken by government of Semarang City were a curative strategy; it was necessary to strive for preventive strategies to prevent the inundation. By knowing the main cause of the problem, the proper decision and strategy could be taken to carry out the problem.

\section{Acknowledgement}

The author would like to acknowledge to Head of Research Centre for Marine and Coastal Resources, Agency of Marine and Fisheries Research, Ministry of Marine and Fisheries providing fully both financial and technical support for this research.

\section{References}

[ACCCRN] Asians Cities Climate Change Resiliance Network. 2010. Kajian Kerentanan dan Adaptasi Terhadap Perubahan Iklim di Kota Semarang. Laporan Akhir. Mercy Corps. Jakarta.

[Bappeda Kota Semarang] Badan Perencanaan Pembangunan Daerah, Kota Semarang. 2011.

Denirkesen, Ali C., Fatih Evrendilek, Suha Berberoglu. 2008. Quantifying Coastal Inundation Vulnerability of Turkey to Sea Level Rise, Environ Monit Assess (2008)138:101-106

Huang, Zhenguo, Yongqiang Zong, Weiqiang Zhang. 2004. Coastal Inundation due to Sea Level Rise in The Pearl River Delta, China. Natural Hazard 33: 247-264

Kumar C.S, et. al. 2008. Inundation mapping, a study based on December 2004 Tsunami Hazard along Chennai coast, Southeast India. Nat Hazards Earth Syst Sci vol. 8: 617-626. http:// www.nat-hazards-earth-syst-sci.net/8/617/2008/

Marfai MA. 2004. Tidal Flood Hazards Assessment: Modelling in Raster GIS, Case in Western Part of Semarang Coastal Area. Indonesian Journal of Geography Vol. 36 (1):25-28.

Miladan N. 2009. Kajian Kerentanan Wilayah Pesisir Kota Semarang erhadap Perubahan Iklim. Thesis pada Program Studi Magister Teknik Pembangunan Wilayah dan KotaProgram Pascasarjana Universitas Diponegoro, Semarang

Nicholls R.J., Wong P.P., Burkett V., Woodroffe C.D. and Hay, J., 2008, Climate change and coastal vulnerability assessment: skenarios for integrated assessment, Sustainable Science (3):89-102

Petrucci, O. and M. Polemio. 2007. Flood risk mitigation and anthropogenic modifications of a coastal plain in southern Italy: combined effects over the past 150 years. Nat. Hazards Earth Syst. Sci. 7:361-373 http://www.nat-hazards-earth-syst-sci.net/7/361/2007/

Suhelmi, Ifan Ridlo. 2013. Pemetaan Kapasitas Adaptif Wilayah Pesisir Semarang dalam Menghadapi Genangan Akibat Kenaikan Muka Air Laut dan Perubahan Ikli.Jurnal Forum Geografi Volume 27 No 2 Tahun 2013, Surakarta, ISSN 0852-2682

Suhelmi, Ifan R. dan Hari Prihatno. 2014. Model Spasial Dinamik Genangan Akibat Kenaikan Muka Air Laut di Pesisir Semarang. Jurnal Manusia dan Lingkungan. Vol. 21, No.1, Maret. 2014: 1-6

Titus JG et al. 1991. Greenhouse Effect and Sea Level Rise: The Cost of Holding Back the Sea. Coast Manage. Vol. 19: 171-204 www.epa.gov/climatechange/effects/downloads/cost_of_ holding.pdf [1 Agustus 2015].

Wibowo DA. 2006. Analisis Spasial Daerah Rawan Genangan Akibat Kenaikan Pasang Surut (Rob) di Kota Semarang. Skripsi Sarjana Jurusan Ilmu Kelautan Fakultas Perikanan dan Ilmu Kelautan Semarang: Universitas Diponegoro. 